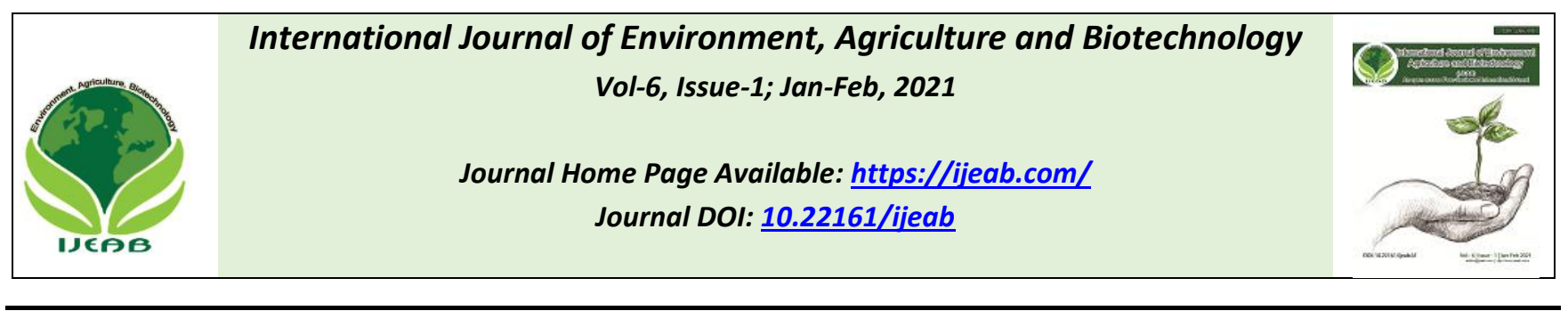

\title{
Effects of Cement dust on Vegetation around Sokoto Cement Company
}

\author{
M.M. Warrah ${ }^{1}$, Senchi, D.S ${ }^{2}$, I.M. Fakai ${ }^{3}$, U.M. Daboh ${ }^{1}$ \\ ${ }^{1}$ College of Agriculture Zuru, Kebbi State, Nigeria \\ ${ }^{2}$ Department of Pure and Applied Chemistry, Kebbi State University of Science \&Technology, Aliero, Nigeria \\ ${ }^{3}$ Department of Biochemistry, Kebbi State University of Science \&Technology, Aliero, Nigeria \\ Corresponding Author: bondesamaila@gmail.com
}

Received: 12 Nov 2020; Received in revised form: 21 Dec 2020; Accepted: 01 Jan 2021; Available online: 11 Jan 2021

(C)2021 The Author(s). Published by Infogain Publication. This is an open access article under the CC BY license

(https://creativecommons.org/licenses/by/4.0/).

\begin{abstract}
The heavy metal deposition around Sokoto Cement Company was investigated to the extent of pollution caused by this industry. Eighty eight samples of plants were separately collected from the four directions of the company into polythene bags and brought to the laboratory for further analyses. The sample were digested using Aqua Regia Method, and the $\mathrm{Hg}, \mathrm{Zn}, \mathrm{Cd}, \mathrm{Cr}, \mathrm{Ni}, \mathrm{Pb}$ and $\mathrm{Cu}$ contents were determined by (AAS). Data generated were subjected to Analysis of Variance (ANOVA) to depict the differences and the means were separated with the Duncan Multiple Range Test (DMRT), where significant differences occur. It was found that the concentration of each heavy metal decreased with increase in distance from the industry. It was further found that heavy metals contributed differently to the pollution status of the environment with the eastern part impacting most. Mercury was found to be present in high concentrations in all the plant materials. Zn was the least except for the southern part where Pb was the least. Sokoto Cement campany was found to produce the wastes/ dust that pollutes the environment and acacia nilotica can be used as biomonitor.
\end{abstract}

Keywords-Soil pollution, Vegetation, Heavy metals and Ecosystem.

\section{INTRODUCTION}

Air pollutants responsible for vegetation injury and crop yield losses are causing increased concern in the environment (Fuji, 1973). Air pollution has become a major threat to the survival of plants in the industrial areas (Gupta and Mishra, 1994). Rapid industrialization and addition of the toxic substances to the environment are responsible for altering the ecosystem (Mudd and Kozlowski, 1975; Clayton and Clayton, 1982; Niragau and Davidson, 1986). The cement industry also plays a vital role in the imbalances of the environment and produces air pollution hazards (Stern, 1976). In comparison with gaseous air pollutants, many of which are readily recognized as being the cause of injury to various types of vegetation, relatively little is known and limited studies have been carried out on the effects of cement dust pollution on the growth of plants. Reduction in the number of flowers and yield of black gram (Vigna mungo (L.) Hepper) as observed by Prasad and Inamdar, (1990) were due to cement dust pollution. The effect of cement and stone dust on the stomatal clogging of Iphoniagrantioides Boiss, leaves were found by Abdullah \& Iqbal, (1991). Lerman and Darle, (1975) observed a marked reduction in the growth of a popular tree Carissa carandas L. 1mile away from the cement plant. Stratmann and van Haut, (1966) dusted plants with quantities of dust ranging from 1 to $48 \mathrm{~g} / \mathrm{m}^{2}$ per day; dust falling on the soil caused a shift in $\mathrm{pH}$ to the alkaline side, which was unfavorable to oats but favorable to pasture grass. Darley et al., (1966) noted that plants were stunted and had few leaves in the heavily dusted portions of an alfalfa field downwind from a cement plant in California. Brandt and Rhoades, (1972) observed significant changes in the structure and composition of the seedling, shrub, sapling and tree strata 
when they compared dusted and non-dusted forest communities in the vicinity of limestone quarries and processing plants.

Air pollution is a social disease, a disease generated primarily from the activities of man and adversely affecting his health and welfare (Gilette, 1984). Pollution stress can alter plant growth and quality and the effects are often extensive (Sagar et al., 1982). We are facing the fact that in relatively recent times, the total amount and complexity of toxic pollutants in the environment are increasing day by day. Karachi, the most industrialized and largest city in Pakistan, is suffering from heavy cement dust pollution originating from the cement industry. The cement dust is the source of particulate matter deposits on the buildings and plants. Despite these adverse effects, cement is widely used in building and construction works and a key ingredient in concrete products. It is a binding agent that holds sand and other aggregates together in a hard stone like mass.

\section{MATERIALS AND METHODS}

\section{COLLECTION OF SAMPLES}

Eighty eight samples of twigs of Acacia nilotica samples were collected in the vicinity of the factory (between the months of August-October,2011) at interval of 50m from the mill, that is at (11) different points $(50 \mathrm{~m}, 100 \mathrm{~m}, 150$ $\mathrm{m}, 200 \mathrm{~m}, 250 \mathrm{~m}, 300 \mathrm{~m}, 350 \mathrm{~m}, 400 \mathrm{~m}, 450 \mathrm{~m}, 500 \mathrm{~m}$ and $1 \mathrm{~km}$ ) from the mill, in which $1 \mathrm{~km}$ served as Control point along each of the four cardinal points (i.e. East, West, South and North). The twigs of A.nilotica samples were collected and packed in clean polythene bags and taken to the laboratory for chemical analysis.

Acacia nilotica were choosen as plant sample because the species is found abundant in the study area and is quite tolerant to heat $\left(>50^{\circ} \mathrm{C}\right)$ and air dryness, It is also frost sensitive. These make the plant to withstand different period and accumulate heavy metals. Twigs of $A$ nilotica were collected from different trees in each direction at $50 \mathrm{~m}$ interval and $1 \mathrm{~km}$ as control point by using measuring tape, hand glove and stainless steel pen-knife. The plant samples were packed in separately clean polythene bags and were brought to laboratory for analysis.

\section{DIGESTION OF PLANT SAMPLES}

Plant samples of A. nilotica were crushed and oven dried at $60^{\circ} \mathrm{C}$. One gram of each crushed sample was weighed into $125 \mathrm{ml}$ Erlenmeyer flask, which has been previously sterilized with acid, (Perchloric acid) and thoroughly rinsed with distilled water. The plant samples were subjected to wet digestion as follows; $4 \mathrm{ml}$ of perchloric acid, $25 \mathrm{ml}$ conc. $\mathrm{HNO}_{3}$ and $2 \mathrm{ml}$ conc. $\mathrm{H}_{2} \mathrm{SO}_{4}$ were added in a fume hood into each sample contained in the flask. The contents were mixed and heated gently at medium heat on a hot plate under Perchloric acid fume hood until dense white fumes appear. The contents were heated strongly again for a minute and allowed to cool. Then $50 \mathrm{ml}$ distilled water was added and allowed to boil for half a minute on the same hot plate at medium heat.

The contents were allowed to cool and each solution was filtered using whatman No 42 filter paper into $100 \mathrm{ml}$ Pyrex volumetric flask. (A.O.A.C., 1990). The digested samples were analyzed for the cadmium $(\mathrm{Cd})$, chromium $(\mathrm{Cr})$, lead $(\mathrm{Pb})$, nickel $(\mathrm{Ni})$, copper $(\mathrm{Cu})$, zincs $(\mathrm{Zn})$ and mercury $(\mathrm{Hg})$ using Atomic Absorption Spectrophotometeric method (AAS).

\section{METHODS}

\section{DETERMINATION OF HEAVY METALS IN PLANT SAMPLES}

The digested samples were separately analyzed for $\mathrm{Cd}, \mathrm{Cr}$, $\mathrm{Pb}, \mathrm{Ni}, \mathrm{Cu}, \mathrm{Zn}$ and $\mathrm{Hg}$ by Atomic absorption spectrophotometeric method. The radiation lamp for each heavy metal to be analyzed was placed in a compartment in the AAS and a tiny pipe attached to the machine (Aspirator) was put inside bottle containing the sample and the concentration of the respective heavy metal was read off by the aid of computer system attached to the machine.

\section{DATA ANALYSES}

Data generated from the quantification of heavy metals were subjected to descriptive and inferential statistics. Their concentrations were compared with respect to location/site with the use of analysis of variance (ANOVA). The means were separated with the use of Duncan multiple range test (DMRT).The data obtained from the chemical analysis were also subjected to statistical treatment using correlation coefficient matrices. This was carried out in order to establish association and probable source of dispersion or pollution 


\section{RESULTS}

Table 1: Concentration of Cadmium $(\mathrm{mg} / \mathrm{l})$ in plant samples around Sokoto cement Company

\begin{tabular}{lcccc}
\hline Distance $(\mathrm{m})$ & North & & South & East \\
\hline 50 & 7.98 & 7.46 & 8.66 & 8.39 \\
100 & 7.91 & 7.47 & 8.59 & 8.41 \\
150 & 7.72 & 7.01 & 8.61 & 8.28 \\
200 & 7.64 & 6.98 & 8.69 & 8.29 \\
250 & 7.72 & 6.99 & 8.63 & 8.21 \\
300 & 7.72 & 6.86 & 8.58 & 8.26 \\
350 & 7.64 & 5.01 & 8.56 & 8.18 \\
400 & 7.69 & 4.91 & 8.58 & 8.14 \\
450 & 7.41 & 4.88 & 8.41 & 8.16 \\
500 & 7.51 & 4.89 & 8.39 & 7.92 \\
1000 & 0.07 & 0.06 & 0.07 & 0.08
\end{tabular}

Table 2: Concentration of Chromium $(\mathrm{mg} / \mathrm{l})$ in plant samples around Sokoto Cement Company

\begin{tabular}{lcccc}
\hline Distance $(\mathrm{m})$ & North & South & East & West \\
\hline 50 & 3.86 & 2.21 & 5.82 & 5.02 \\
100 & 3.82 & 2.08 & 5.79 & 5.01 \\
150 & 4.01 & 1.92 & 5.83 & 4.82 \\
200 & 3.46 & 1.71 & 5.88 & 4.51 \\
250 & 3.01 & 1.68 & 5.46 & 4.49 \\
300 & 3.21 & 1.56 & 5.48 & 4.48 \\
350 & 2.98 & 0.92 & 5.56 & 4.41 \\
400 & 2.86 & 1.02 & 5.32 & 4.01 \\
450 & 2.48 & 1.21 & 4.98 & 4.09 \\
500 & 2.29 & 0.99 & 4.66 & 4.28 \\
1000 & 0.08 & 0.07 & 0.08 & 0.07
\end{tabular}

Table 3: Concentration of Copper $(\mathrm{mg} / \mathrm{l})$ in plant samples around Sokoto Cement Company

\begin{tabular}{|c|c|c|c|c|}
\hline Distance (m) & North & South & East & West \\
\hline 50 & 1.08 & 0.71 & 3.08 & 1.72 \\
\hline 100 & 1.10 & 0.88 & 2.06 & 1.84 \\
\hline 150 & 1.06 & 0.62 & 2.18 & 1.48 \\
\hline 200 & 1.09 & 0.61 & 2.68 & 1.26 \\
\hline 250 & 1.09 & 0.64 & 2.32 & 1.31 \\
\hline 300 & 1.02 & 0.59 & 2.01 & 1.46 \\
\hline 350 & 1.04 & 0.51 & 2.11 & 1.21 \\
\hline 400 & 1.02 & 0.41 & 2.22 & 1.19 \\
\hline
\end{tabular}




$\begin{array}{lllll}450 & 0.78 & 0.41 & 1.89 & 1.21 \\ 500 & 0.68 & 0.32 & 1.68 & 1.11 \\ 1000 & 0.07 & 0.04 & 0.07 & 0.08\end{array}$

Table 4: Concentration of Mercury (mg/l) in plant samples around Sokoto Cement Company

\begin{tabular}{lcccc}
\hline Distance $(\mathrm{m})$ & North & South & East & West \\
\hline 50 & 11.12 & 10.81 & 12.33 & 11.68 \\
100 & 11.22 & 10.62 & 12.66 & 11.70 \\
150 & 11.18 & 10.46 & 12.61 & 11.70 \\
200 & 11.14 & 10.4 & 12.69 & 11.42 \\
250 & 11.02 & 9.86 & 12.21 & 11.51 \\
300 & 11.08 & 9.48 & 12.19 & 11.31 \\
350 & 11.08 & 7.21 & 12.16 & 11.29 \\
400 & 10.92 & 6.98 & 12.04 & 11.28 \\
450 & 10.64 & 6.92 & 11.89 & 11.32 \\
500 & 10.78 & 7.01 & 11.66 & 2.24 \\
1000 & 2.21 & 2.10 & 2.35 & \\
\hline
\end{tabular}

Table 5: Concentration of Nickel ( $\mathrm{mg} / \mathrm{l})$ in plant samples around Sokoto Cement Company

\begin{tabular}{rllll}
\hline Distance $(\mathrm{m})$ & North & South & East & West \\
\hline 50 & 2.38 & 1.99 & 10.62 & 7.01 \\
100 & 2.39 & 2.09 & 10.01 & 6.21 \\
150 & 2.41 & 1.99 & 9.86 & 5.89 \\
200 & 2.21 & 2.09 & 9.66 & 5.86 \\
250 & 2.01 & 9.01 & 4.92 \\
300 & 2.26 & 2.08 & 8.08 & 2.64 \\
350 & 1.97 & 8.19 & 3.08 \\
400 & 2.18 & 1.98 & 8.16 & 2.98 \\
450 & 2.09 & 1.92 & 7.18 & 2.89 \\
500 & 2.01 & 1.88 & 7.16 & 2.48 \\
1000 & 2.16 & 0.09 & 0.07 & 0.09 \\
\hline
\end{tabular}

Table 6: Concentration of Lead $(\mathrm{mg} / \mathrm{l})$ in plant samples around Sokoto Cement Company

\begin{tabular}{ccccc}
\hline Distance $(\mathrm{m})$ & North & South & East & West \\
\hline 50 & 2.61 & 2.07 & 3.08 & 3.02 \\
100 & 2.62 & 2.09 & 3.08 & 2.98 \\
150 & 2.62 & 1.88 & 3.11 & 2.99 \\
200 & 2.51 & 1.89 & 3.09 & 2.92 \\
250 & 2.53 & 1.86 & 3.06 & 2.91
\end{tabular}




$\begin{array}{ccccc}300 & 2.41 & 1.89 & 3.05 & 2.87 \\ 350 & 2.39 & 1.34 & 3.09 & 2.85 \\ 400 & 2.38 & 1.38 & 3.04 & 2.72 \\ 450 & 2.41 & 1.36 & 3.01 & 2.62 \\ 500 & 2.06 & 1.33 & 2.02 & 2.66 \\ 1000 & 0.08 & 0.07 & 0.04 & 0.06\end{array}$

Table 7: Concentration of Zinc $(\mathrm{mg} / \mathrm{l})$ in plant samples around Sokoto Cement Company

\begin{tabular}{cllll}
\hline Distance $(\mathrm{m})$ & North & South & East & West \\
\hline 50 & 0.53 & 0.42 & 1.31 & 1.04 \\
100 & 0.48 & 0.36 & 1.31 & 1.06 \\
150 & 0.56 & 0.31 & 1.29 & 0.98 \\
200 & 0.54 & 0.29 & 1.24 & 0.99 \\
250 & 0.43 & 0.26 & 1.16 & 1.01 \\
300 & 0.39 & 0.22 & 1.19 & 0.92 \\
350 & 0.39 & 0.17 & 1.18 & 0.89 \\
400 & 0.41 & 0.16 & 1.09 & 0.99 \\
450 & 0.29 & 0.19 & 1.02 & 0.88 \\
500 & 0.32 & 0.18 & 1.08 & 0.86 \\
1000 & 0.06 & 0.06 & 0.06 & 0.06 \\
\hline
\end{tabular}

\section{DISCUSSION}

The analysis shows a considerable abundance of the toxic metals on the vegetation around Sokoto Cement Company and its immediate environments. It was discovered that the concentrations of all the metals are high in plant samples at various directions. The high concentration of the metals could be probably due to limited number of vegetation around the factory. The higher heavy metal concentrations observed in this study may be attributed to deposition of calcium oxide from Cement Company and calcium compounds in the soils of Sokoto. Brady and Weil, (1999) reported that the neutral to alkaline soil $\mathrm{pH}$ observed in semi-arid soil such as that of Sokoto was due to low rainfall and alkaline compounds are not leached away, thus making soils of the region too alkaline. This is in support of the result of this study because the concentrations of cadmium $(\mathrm{Cd})$, chromium $(\mathrm{Cr})$, lead $(\mathrm{Pb})$, nickel $(\mathrm{Ni})$, copper $(\mathrm{Cu})$, zinc $(\mathrm{Zn})$ and mercury $(\mathrm{Hg})$ in plant samples is high.

Gbadebo and Bankole, (2007) analysed potentially toxic metals in airborne cement dust around Sagamu, Southwestern Nigeria. The heavy metals investigated are $\mathrm{As}, \mathrm{Al}, \mathrm{Ca}, \mathrm{Cd}, \mathrm{Pb}, \mathrm{Co}$, and $\mathrm{Zn}$. They reported elevated concentrations of these heavy metals and inducted them in the health problems among the inhabitants of the communities. Their observed confirmed favorably with the finding of this study. The result obtained in this study inducted potential environmental problems such as destruction of vegetation cover and environmental degradation (Topie, 1999; Hegazy 1996; Raguotis, 1997). For example, Topie, (1999) indicated that the cement industry was the main cause of destruction of vegetation cover and of environmental degradation in Solin and Kastela near Spilt, Croatia. Damages to coniferous trees by cement dust have been reported by Mandre and Tuulmets, (1997).

Cement dust had a significant effect on the growth of some plant species compared with non-cement dusted plants. Toxic compounds such as fluoride, magnesium, lead, zinc, copper, beryllium, sulfuric acid and hydrochloric acid were found to be emitted by cement manufacturing plants (Andrej, 1987).This support the result of this study which showed that cadmium, chromium, copper, mercury, nickel, lead and zinc are available in soil around Sokoto Cement Company. Reduction in plant height, cover and number of leaves of $C$. carandas showed that the losses can generally 
be attributed to the cement dust which contained toxic metals. The results obtained are in close conformity with those reported by Stratmann and Van Haut, (1966) who dusted plants with dust ranging from 1 to $48 \mathrm{~g} / \mathrm{m}^{2}$ day $^{-1}$ and concluded that dust falling on the soil caused a shift in $\mathrm{pH}$ to the alkaline side. The findings of Prasad and Inamdar, (1990) in Vignamungo (Black gram) also confirmed the finding of this study. The cement dust kiln showed a reduction in chlorophyll content, protein, starch, yield and phytomass in ground nuts (Arachis hypogaea L.) (Prasad \& Inamdar, (1990). Liu et al., (1997) reported that cement dust decreased the yield of grape and rice in the vicinity of a cement factory in China. It has also been indicted in the reduction of crop yield.

Plant response varies between species of a given genus and between varieties within a given species. Plants do not necessarily show similar susceptibility to different pollutants. Major variations in response to different species to air pollutants have been documented by Jacobson and Hill, (1970). Studies of biochemical changes and pollution effects on the plant metabolism, i.e., reduction in chlorophyll and completely clogged stomates (Ahmed and Qadir, 1975) revealed that these parameters are important in regulating the productivity and also the number of flowers and seeds produced.

Cadmium, chromium, copper, mercury, nickel, lead and zinc that are prominent in cement dust were found to be higher in concentration in the samples analyzed. This indicates the extent to which the soil and vegetation were polluted by the cement dust from the Sokoto cement company. The concentrations of heavy metals are higher in eastern and western part followed by north and least was southern part of the company, the higher concentrations of heavy metals in eastern and western parts was attributed due to the loading of Cement and heavy trucks movement in the east and presence of quarry and production activities in western part of the Company. Ade-Ademilua and Umebese (2007) have pointed out that metal to metal association could cause an increase in concentration of other metal (absent in cement dust) in the polluted soil over time. Forstner (1995) also pointed out that $70 \%$ of metals contaminated soils involved two or more metals and the possibility of synergistic effects may be of considerable importance at some heavy metals contaminated sites.

The significant reductions in shoot length and total leaf area observed in the polluted plants have also been reported in the works of Singh and Rao (1981); Ayanbamiji (1996) and Igbal and shafoeg (1998). The reduction may be due to toxicity of heavy metals which Rout etal., (2000) stated that once inside the cells, the aluminium could inhibit root absorption and growth in both aluminium sensitive and tolerant plants. The significant decrease in vegetative growth of polluted plants may be an indication of a reduction in photosynthesis of polluted plants which could be explained on the bases of quantitative as well as qualitative changes in the incident light available for photosynthesis in cement encrusted leaves (Bohne,1963), interruption in gaseous through stomatal clogging (Darley etal.,1966;Lerman, 1972), reduction in transpiration in terms of the absorption of minerals from soil and inhibition of intracellular processes (Singh and Rao,1981).

The cement dust caused the epidermal cells and stomata of the polluted leaves to become modified.The higher stomata frequency and index in the leaves of the polluted plants indicate morphological modification on the leaves. According to Ayanbamiji (1996), these may be adaptations for gaseous exchange and transpiration since the surfaces are covered by cement dust.

Studies of the effects of cement-kiln dust deposited on the soils also raised questions. Some investigators reported no harmful effects of cement at levels from 1.5 to 7.5 $\mathrm{g} / \mathrm{m}^{2} /$ day, while others reported that concentrations from 1.0 to $48 \mathrm{~g} / \mathrm{m}^{2} /$ day caused shifts in the soil alkalinity which may be favorable to one crop but harmful to others (Lerman and Darley, 1975) thus confirming the result of this study whose reported higher concentrations of heavy metal in soil samples.On the analytical assessment of some trace metals in soils around the major industrial areas of Northwestern Nigeria and Sokoto Cement Company reported higher mean concentrations of heavy metals: $\mathrm{Cd}$ (0.10 ug/g); $\mathrm{Cr}(83.4 \mathrm{ug} / \mathrm{g}) ; \mathrm{Pb}(486 \mathrm{ug} / \mathrm{g})$ and $\mathrm{Ni}(22.9$ $\mathrm{ug} / \mathrm{g})$. This study also showed higher concentration of heavy metals investigated, the mean values are $\mathrm{Cd}(16.9 \mathrm{mg} / \mathrm{l}), \quad \mathrm{Cr}(15.2 \mathrm{mg} / \mathrm{l}), \quad \mathrm{Pb}(8.30 \mathrm{mg} / \mathrm{l}) \quad$ and $\mathrm{Ni}(9.03 \mathrm{mg} / \mathrm{l})$ which are within the range reported by Abubakar etal., (2006); Birnin Yauri and Argungu (2002).

Adejumo et al., (1994) showed that some toxic heavy metals like arsenic (AS), lead (Pb,) nickel (Ni), cobalt $(\mathrm{Co})$, zinc $(\mathrm{Zn})$, copper $(\mathrm{Cu})$ and phosphorus $(\mathrm{P})$ were significantly enriched in the neighbourhood of cement factories in Nigeria. This can lead to reduction of soil fertility, Adejumo et al., (1994), it has also been linked to the damage of dwellings (Perfettini et al., 1989. Deposit of cement dust on roofs can cause microbiological and chemical disintegration of the roofs. Wasserbauer etal., (1998) indicated that metabolic process of nitrifying bacteria (mainly Nitrosomonas and Nitrobacter) on cement dust which settle on roofs can cause chemical corrosion of the roofing materials thereby increasing porosity and weakening the strength of roofing materials. 
On the basis of this study, it could be said that vegetation around Sokoto Cement Company was found to be affected by cement dust, which might be due to the presence of different toxic pollutants in cement dust. The biological behavior of vegetation e.g A nilotica was found to be highly affected due to the present of different heavy metals found in the twig of the plant. It is clear that the cement dust pollution is an operative ecological factor causing deterioration in the quality of our environment (Shah etal., 1989). It is concluded that the presence of toxic pollutants in cement dust might be responsible for the reduction in vegetation and soil fertility. Traces of toxic metals such as chromium and copper are common in some varieties of Portland cement and are harmful to human beings and other living systems (Omar and Jasim, 1990). The heavy metals present in the cement dust can play an important role in disturbing the various metabolic processes of plant. The growth metabolic processes and yield of winter barley were found to be affected by the Duna cement and lime works (Borka, 1986), in an experiment of six kinds of dust which contained heavy metals introduced under the stand canopy. The dust was collected from zinc, cadmium, aluminum, iron plants, electric power station and the cement plant. The dust was introduced in concentrations of 100, 500, 1000, 2000 and $5000 \mathrm{t} \mathrm{Km}^{-2}$. The experiment proved that the cement dust brought about changes in the ecosystem. A link between the forest ecosystem under the influence of heavy metals in dust and the effect of these changes on the growth of pine stands was also obtained.

The levels at which the toxic elements were found in both plants and soil sample around the factory in this study showed that they have exceeded regulatory standards, $\mathrm{Cd}$ (0.005ug g- $\left.{ }^{1}\right)$; $\mathrm{Cr}\left(0.02 \mathrm{ug} \mathrm{g-}^{1}\right)$; $\mathrm{Pb}\left(0.05 \mathrm{ug} \mathrm{g-}{ }^{1}\right)$ and $\mathrm{Ni}$ (0.5ug g- $\left.{ }^{1}\right)$ Fell et al., (2003). It showed that the cement plant is seriously polluting the environment and it confirmed the assertion of Bilen (2010) that cement production is of the main sources of environmental pollution. It also showed that control strategies for prevention of dust release by cement plants have not been implemented in the cement company. Fell et al., (2003) said that in advanced countries, control-strategies for the prevention of dust release by machinery enclosure, local exhaust ventilation, work automation and greater diligence in maintenance of machinery have been implemented, presumably leading to less dust exposure.

\section{CONCLUSION}

This research has shown that there is a significant emission of cement dust into the environment around Sokoto Cement Company, up to $1000 \mathrm{~m}$ distances from the mill in the four cardinal directions. This dusts emitted are capable of posing a serious problem to vegetation and soil fertility even at a distance of $1000 \mathrm{~m}$ away from the mill. This study has established that higher concentrations of heavy metals both in plant and soil samples $(\mathrm{Cd}, \mathrm{Cr}, \mathrm{Cu}, \mathrm{Hg}, \mathrm{Pb}$, $\mathrm{Ni}$ and $\mathrm{Zn}$ ) were obtained in different locations. It could be concluded that vegetation and soil around Sokoto Cement Company were found to be affected by cement dust, which might be due to the presence of different toxic pollutants in cement dust. The biological behavior of vegetation ( $A$ nilotica) was found to be highly affected due to the presence of different heavy metals found in the twigs of the plant. It was found that the concentrations of heavy metals were highest in eastern part followed by western then the northern part and the least was southern part of the company. It is clear that the cement dust pollution is an operative ecological factor causing deterioration in the quality of our environment (Shah etal., 1989). I therefore recommend that to safeguard the quality of vegetation around the company, the cement factory management should embark on regular/periodic monitoring of cement dust level in and around the factory environment, and should reduce the dust emission by the use of dust filters.

\section{REFERENCES}

[1] Abdulrahman, F.W. Inuwa, M. Birnin Yauri , U.A. and Ibrahim, S.A. (2007). Analytical assessments of some trace metals in Soils around the major industrial Areas of Northern Nigeria. Academic Journals Inc., (2) 6: 515-521.

[2] Abubakar, U. Adamu, T and Ishaku, N.T. (2006): Prevalence of Urinary Schistosomiasis Among Inhabitants of Four Local government of Sokoto State. Nigeria journal of Basic and Applied Sciences Vol. 14 (1\&2). P 23

[3] Ade-Ademilua, O.E. and Umebese, (2007). The growth of Phaseolus vulgaris L. CV. Ife Brown (Leguminosae) in a cement side rich in heavy metals. Pak. J. Biol. Sci., 10(1): 182-185.

[4] Adejumo, J.A. Obioh, I.B. Ogunsola, O.J. Akeredolu, A.F. Olaniyi, H.B. Asubiojo, O.I. Oluwole, F.A. Akanle, O.A. and Spyrou, N.M. (1994)."The Atmospheric Deposition of major, minor and trace elements within and around three cement factories." Journal of Radio Analytical and NuclearChemistry, 179(2): 195-204

[5] Ahmed Z. and Qadir S.A (1975). The effects of air pollution on stomatal clogging, carbohydrate and chlorophyll contents in certain roadside plants. Pakistan Journal of Botany 7: 81-84.

[6] AOAC, (1990). Official Methods of Analysis. 15th Edn. Association of Official Analytical Chemists,WashingtonDC.,USA.,Pp: 200-210.

[7] Ayanbamiji, T.A. (1996). The effect of cement dust on some plant growing in the surrounding ofWest Africa Portland cement Company, Ewekoro. Morphology and level of calcium, iron, silicon and aluminium. M.Sc Thesis, University of Lagos, Nigeria. 
[8] Ayanbamiji, T.A. (1996). The effect of cement dust on some plant growing in the surrounding of West Africa Portland cement Company, Ewekoro. Morphology and level of calcium, iron, silicon And aluminium. M.Sc. Thesis, University of Lagos, Nigeria.

[9] Bilen, S. (2010). Effect of cement dust pollution on microbial properties and enzyme activities in Cultivated and no-till soils. Afr. J. Microbiol. Res., 4:2418-2425.

[10] Bohne, H. (1963). Schädlichkeit von Staub aus Zementwerken für Waldbestände. Allg. Forst., 18, 107111

[11] Borka, G. (1986). Effects of cement dust on the growth development, major metabolic processes and Yield of winter barley Òin situÓ and under controlled conditions. Acta Agron Hungary 35(1/2): 45-52.

[12] Brady, N.C. and Weil, R.P. (1999). The nature and properties of soil: twefth edition. Upper saddle River. $N \mathrm{~J}$; prentice Hall. Pp 446-490.

[13] Brandt C.J. and Rhoades, R.W (1972). Effects of limestone dust accumulation on composition of a forest community. Environmental Pollution 3: 217-225.

[14] Clayton, G.D. and Clayton, F.E (1982). Pattys industrial hygiene and technology, Wiley Interscience, New York.

[15] Darley, G.D.E.F. Drugger, W.M. Mudd, J.B. Ordin, L. Taylor, O.C, and Stephe ， E.R. (1966). Plant damage by pollution derived from auto mobiles. Arch Environment Health 6: 700-761.

[16] Fell, A.K.M. Thomassen, T.R. Kristensen, P. Egeland, T. and Kongerud, J. (2003). Respiratory symptoms and ventilatory function in workers exposed to Portland cement dust. J. Occup. Environ. Med., 45: 1008-1014.

[17] Forsner, V. (1995). Land contamination of metals .In: Metals speciation and contamination of soil,Allen, $\mathrm{H}$. (Ed). Lewis publishers, London, PP: 1-33.

[18] Fuji, S. (1973). The current state of plant damage by air pollution in Okayama Perfecture. Shokbutsu Boeki, 27: 249-252.

[19] Gbadebo, A.M. and Bankole, O.D. (2007). Analysis of potentially toxic metals in airborne cement dust around sagamu, Southwestern Nigeria. J. Applied Sci., 7: 35-40.

[20] Gillette, D.G. (1984). Concern about atmospheric pollution. In: Treshow M (ed.) Air Pollution and Plant Life, pp. 7-13. New York: John Wiley and Sons.

[21] Gupta, A.K. and Mishra, R.M. (1994). Effect of lime kilnÕs air pollution on some plant species.Pollution Research 13(1): 1-9.

[22] Hegazy, A.K. (1996). "Effect of cement kiln dust pollution on the vegetation and seed bank species diversity in the eastern desert of Egypt." EnvironmentalConservation, 23(3): 249-252.

[23] Iqbal, M.Z. and Shafoeg, M. (1998). Toxicity of cement dusts on the growth of some tree seedlings.EcologiaBratislava, 17: 434-439.

[24] Jacobson, J.S. Hill, A.C. (1970). Recognition of Air Pollution Injury to Vegetations: A Pictorial Atlas. Air Pollution Control Association Pittsburgh. Pennsylvania.
[25] Lerman, S.L. Darley, E.F. (1975). Particulates, In. Responses of Plants to Air Pollution. Pp. 141. New York: Academic Press.

[26] Liu, J.L. Du, M. Shang, K.Y. Chen, S.Y. Xu, H.B. and Xie, M.Y. (1997). The effects of cement dust pollution on rice, rape and soil. J Plant Resources Environ 6, 42-47.

[27] Mandre, M. and Tuulmets, L. (1997). "Biochemical diagnosis of forest decline." Baltic Forestry, 3 (2): 19-25

[28] Mudd J.B. and Kozlowski T.T. (1975). Response of plants to air pollution. Academic Press, New York. Pp383.

[29] Niragau, J.O. Davidson, C.I. (1986). Toxic metals in the atmosphere, John Wiley and Sons. New York.

[30] Omar, J.M. and Jasim, F. (1990). Some observations on the use of electrothermal atomic absorption spectorpotometry for the determination of chromium and copper in Portland cement. Microchemistry Journal41(3): 348-355.On groundnut. Indian Bot Cont; 7(4): 159-162.

[31] Perfettini, J.V. Lango, N. Mazino, E. Reverbegat, J.K. Petit, C.C. Gaylende and Mortan,L.H.G. (eds). (1989). Evaluation of the Cement Degradation Induced by the Metabolic Products of Two Fungal Strains. Biodeterioration Society occasional Publication No 5.

[32] Prasad, M.S.V. and Inamdar, J.A. (1990). Effect of cement kiln dust pollution

[33] Ragoutis, A. (1997). "Stability of Forest MarshlandMicroflora within the impact zone of the Akmnescement plant."Miskininkyste,39(1): 128-138.

[34] Rout, G.R. Amantaray, S.S. and As, P.D. (2000). Aluminium toxicity in plants: A review. Plant Biotechnology Division, Regional plant Resource centre, Bhubanes war-751015, Orissa, india.

[35] Sagar, V.K. Gregory, C.P. and Paul, S.J. (1982). Air Pollution. An important issue in plant health. Plant Disease 66: 429-434.

[36] Shah, F.H. Ilahi, I. and Rashid, A. (1989). Effect of cement dust on the chlorophyll contents, stomatal clogging and biomass of some selected plants. Pakistan $J \quad S c i$ Indust Research 32(8): 542-545.

[37] Singh, S. N. and Rao, D. N. (1981). Certain responses of wheat plants to cement dust pollution. Environ. Pollut., A24, 75.78 .

[38] Stern, A.C. (1976). Air Pollution. Measurement, Monitoring and Surveillance of Air Pollution, $3^{\text {rd }}$ ed., Academic Press, New York.

[39] Stratmann, and Van Haut (1966). In: Darley, E.F. Studies on the effect of cement kiln dust on vegetation. Air Pollution Control Association Journal 165(3): 33-39.

[40] Yauri, U.A.B. and Argungu, B.H. (2002). Automobile pollution, a case study of some towns in kebbi state Nigeria. Nig. J. Basic Applied Sci., 11: 147-155.

Topie, V. (1999). "Surface excavation in the area of kastela and the possibilities of Amelioration."Surmarki List, 123(78): 301-309. 